\title{
Upaya Pemberdayaan Guru Oleh Kepala Sekolah Guna Meningkatkan Prestasi Kerja Yang Optimal Pada SD Negeri Tumbang Kalemei
}

\section{Teacher Empowerment Efforts By The School Head To Improve Optimum Work Achievement In SD Negeri Tumbang Kalemei}

\author{
Oleh: Dagan \\ Email: rikuatno_spd@yahoo.co.id
}

\begin{abstract}
ABSTRAK
Penelitian ini dilakukan dengan metode penelitian tindakan kelas yang berlangsung selama 2 siklus. Masing-masing siklus terdiri dari tahapan perencanaan, pelaksanaan, observasi dan refleksi. Pada tahap ini peneliti melaksanakan rencana tindakan supervise individual/kelompok untuk menilai administrasi guru yang sudah dikumpulkan sebelumnya. Pelaksanaan supervise dilakukan dengan pertemuan individual office-conference. Hal ini dilakukan terutama kepada guru yang tidak mengumpulkan perangkat pembelajaran, untuk mengetahui penyebab/masalahnya. Tahap ini peneliti rencanakan berlangsung selama 2 minggu dan dilaksanakan bersama-sama dengan kolaborator. Pelaksanaan inovasi pembelajaran guru sudah melaksankan inovasi sesuai apa yang sudah di arahkan oleh kepala sekolah dan imotivasi. Hal ini ditunjukkan dengna bukti ilmiah adanya peningkatan dari siklus I sebesar 62,50\% menjadi siklus II sebesar 87,50\%. Berdasarkan analisis data yang diperoleh dari presensi kehadiran guru dan keaktifan dalam membuat administrasi guru serta dalam mengajar, diperloeh data bahwa guru mulai menerapkan inovasi dalam pembelajaran di kelas.
\end{abstract}

\section{Kata Kunci: Pemberdayaan Guru, Prestasi Kerja Optimal.}

\section{ABSTRACT}

This research was conducted with a classroom action research method that lasted for 2 cycles. Each cycle consists of planning, implementation, observation and reflection stages. At this stage the researcher implements an personal / group supervision action plan to assess the teacher administration that has been previously collected. Supervision is carried out through individual office-conference meetings. This is done especially for teachers who do not collect learning tools, to find out the cause / problem. This stage the researcher plans to last for 2 weeks and be carried out together with collaborators. Implementing learning innovations, the teacher has carried out innovations according to what has been directed by the principal and motivation. This is indicated by scientific evidence of an increase from cycle I of $62.50 \%$ to cycle II of $87.50 \%$. Based on the analysis of data obtained from the presence of teachers and aliveness in making teacher administration as well as in teaching, data is obtained that teachers are starting to make innovations in classroom learning.

Keywords: Teacher Empowerment, Optimal Job Performance. 


\section{PENDAHULUAN}

Dalam upaya meningkatkan prestasi kerja guru terdapat banyak faktor yang mempengaruhinya, dimana semua faktorfaktor tersebut saling menunjang. Oleh karena itu sebagai seorang pemimpin kepala sekolah harus memperhatikan faktor-faktor yang mempunyai potensi untuk meningkatkan prestasi kerja guru tersebut. Pada dasarnya faktor yang mempengaruhi prestasi kerja guru timbul dari faktor eksternal dan faktor internal. Faktor internal muncul dari dalam diri guru itu sendiri seperti bakat, pengetahuan, dan motivasi. Sedangkan faktor eksternal muncul dari luar diri guru tersebut misalnya lingkungan kerja.

Untuk mengetahui tinggi rendahnya prestasi kerja guru dapat diketahui dari hasil penilaian pelaksanaan pekerjaan yang dilakukan oleh kepala sekolah. Penilaian meruakan usaha untuk membandingkan antara hasil yang nyatanya dicapai dan seharusnya dicapai dengan pedoman yang telah ditetapkan.

Menurut Sikula (Hasibuan, 2001:86) mengungkapkan "Penilaian prestasi kerja adalah evaluasi yang sistematis terhadap pekerjaan yang telah dilakukan oleh karyawan dan ditujukan untuk pengembangan". Sementara itu Tim Dosen Jurusan Adpend (2002:105) mengungkapkan "Penilaian prestasi kerja merupakan usaha yang dilakukan untuk mengetahui seberapa baik performance seorang tenaga kependidikan dalam melaksanakan tugas dan pekerjaannya dan seberapa besar potensinya untuk berkembang".

Permasalahan yang disinyalir oleh peneliti sebagai akar permasalahan dari semua masalah yang teridentifikasi rendahnya kaktifan guru dalam ber inovasi dalam pembelajaran. Masalah utama dalam penelitian ini adalah untuk membuktikan apakah pemberdayaan guru oleh kepala sekolah akan meningkatkan keaktifan guru berinovasi dalam pembelajaran? Untuk memecahkan masalah tersebut, peneliti merencanakan pemecahan masalah dengan melakukan supervise akademik secara berkelanjutan. Metode penelitian ini akan dicobakan selama dua siklus dengan target penelitian semua guru yang berada di lingkungan SD Negeri Tumbang Kalemei. Adapun tujuan penelitian ini adalah untuk membuktikan secara ilmiah apakah pemberdayaan guru oleh kepala sekolah bisa meningkatkan keaktifan guru ber inovasi dalam pembelajaran dan Mengetahui langkah-langkah yang tepat dalam melakukan pemberdayaan guru oleh kepala sekolah agar mampu meningkatkan keaktifan guru dalam berinovasi dalam pembelajaran.

\section{Konsep Pemberdayaan Guru Oleh Kepala Sekolah}

Konsep pemberdayaan berasal dari kata power atau daya sehingga empowerment diartikan sebagai pemberdayaan. Daya mengandung arti kekuatan yang berasal dari dalam, tetapi dapat diperkuat dengan unsur-unsur penguatan yang diserap dari luar (Kartasasmita dalam bukunya Sufyarma 2003:63).

Menurut Engkoswara (1999:119) mendefinisikan "pemberdayaan merupakan pemanfaatan secara maksimal sumber daya yang ada". Dalam hal ini berarti pemberdayaan yaitu dapat memanfaatkan segala potensi yang dimiliki agar dapat 
memiliki nilai guna yang lebih baik. Sedangkan Sufyarma (2003:63) mendefinisikan bahwa "pemberdayaan adalah upaya untuk membangun daya atau potensi manusia dengan upaya mendorong, memotivasi, dan membangkitkan kesadaran akan potensi yang dimilikinya serta berupaya untuk mengembangkannya". Pemberdayaan dalam hal ini mengandung arti memperkuat potensi atau daya dan berupaya untuk mengembangkannya. Adapun menurut Sedarmayanti (2000:79) konsep pemberdayaan memiliki dua kecenderungan yaitu pemberdayaan menekankan pada proses pemberian atau menjalankan sebagian kekuasaan, kekuatan atau kemampuan (power) kepada masyarakat atau individu agar lebih berdaya, proses ini sering disebut sebagai kecenderungan primer dari makna pemberdayaan. Pemberdayaan menekankan pada proses menstimulasi, mendorong, dan memotivasi individu agar mempunyai kemampuan atau keberdayaan untuk menentukan apa yang menjadi pilihan hidupnya.

Tujuan pemberdayaan guru pada dasarnya adalah untuk memperbaiki keefektifan kerja organisasi sekolah, dimana melalui proses pemberdayaan ini guru mempunyai kebebasan dalam pelaksanaan tugas, tanggung jawab, serta dalam pengambilan keputusan sehingga guru dapat lebih berkarya dengan inisiatif dan kreatifitasnya dalam mengembangkan mutu organisasi sekolah. Hal tersebut sejalan dengan pendapat Cook dan Stave (1996) yang dikutip oleh Sedarmayanti (2000:80) yang mengemukakan bahwa "pemberdayaan merupakan sarana perubahan untuk membantu, memperbaiki baik terhadap kepuasan pelanggan maupun karyawan, dan

Dagan dengan demikian juga dapat membantu memperbaiki keefektifan organisasi".

Pemberdayaan merupakan tugas manajer yang tidak boleh diabaikan, begitu pula pemberdayaan guru yang harus mendapat perhatian dari kepala sekolah sebagai pimpinan dimana guru merupakan unsur strategik dalam kelangsungan pengembangan organisasi sekolah. Berikut ini diungkapkan beberapa tahapan yang dapat dilakukan oleh kepala sekolah dalam pemberdayaan guru sebagaimana dikemukakan oleh Patricia Patton yang dialih bahasakan oleh Anita B Hariyanto (2001:81-84) sebagai berikut :

a) Persiapan pemberdayaan guru

b) Pemberian kepercayaan kepada guru

c) Memberikan petunjuk dan arahan

d) Kejelasan visi organisasi

e) Kesiapan sarana (sumber daya non manusia)

f) Hasil yang diharapkan

Moch. Uzer Usman (1995:6)

mengemukakan bahwa "Guru memiliki banyak tugas, baik yang terkait oleh dinas maupun luar dinas dalam bentuk pengabdian". Apabila dikelompokkan terdapat tiga jenis tugas guru yakni tugas dalam bidang profesi, tugas kemanusiaan, dan tugas dalam bidang kemasyarakatan. Dalam dunia pendidikan kepemimpinan merupakan kegiatan dan kemampuan yang dimiliki oleh seseorang dalam mempengaruhi orang lain berupa menggerakan, mengajak, menuntun, dan mengarahkan agar melaksanakan tugasnya sesuai dengan tujuan pendidikan secara efektif dan efisien. 


\section{Konsep Prestasi Kerja Guru}

Manusia pada hakekatnya memiliki kemampuan untuk berprestasi diatas kemampuan orang lain, dengan motivasi yang dapat mendorongnya untuk melakukan sesuatu baik motivasi dari dirinya sendiri maupun motivasi yang berasal dari lingkungan diluar dirinya.

Prestasi kerja merupakan hasil yang telah dicapai oleh seseorang menurut ukuran yang berlaku atas dasar kemampuan dan kemauan yang dimilikinya dalam memahami dan melaksanakan pekerjaan yang menjadi kewajibannya. A.A Anwar Prabu Mangkunegara (2001:67) mengemukakan bahwa "prestasi kerja adalah hasil kerja secara kualitas dan kuantitas yang dicapai oleh seorang pegawai dalam melaksanakan tugasnya sesuai dengan tanggung jawab yang diberikan kepadanya". Prestasi kerja sering diterjemahkan artinya sama dengan kinerja, pelaksanaan kerja, atau penampilan kerja. Seperti yang dijelaskan oleh Sedarmayanti (2001:50) bahwa "performance diterjemahkan menjadi kinerja, juga berati prestasi kerja, pelaksanaan kerja, pencapaian kerja, hasil kerja atau penampilan kerja".

Sementara itu Cooper yang dikutip oleh Sadili Samsudin (2005:159) mendefinisikan "prestasi kerja adalah tingkat pelaksanaan tugas yang dapat dicapai oleh seseorang anggota atau divisi dengan menggunakan kemampuan yang ada dan batasan-batasan yang telah ditetapkan untuk mencapai tujuan organisasi atau perusahaan".

Titik berat tugas seorang guru sebagai tenaga pendidik adalah terletak pada kualitas pelayanan dan usaha yang sungguh-sungguh agar tercapai kinerja yang maksimal. kualitas program pendidikan tidak hanya bergantung pada konsep-konsep program yang cerdas tapi juga pada personil pengajar yang mempunyai kesanggupan dan keinginan untuk berprestasi.

Kemampuan guru untuk memberikan kontribusi kepada kepala sekolah dan mampu mewujudkan sesuatu yang berguna bagi dirinya, penuh ide yang kreatif, berwawasan jauh ke depan, dan senantiasa berupaya memacu dan meningkatkan keterampilan serta pengetahuan sehimgga ia dapat memperoleh hasil kerja yang diharapapkan yang merupakan perwujudan dari prestasi kerja guru yang tinggi.

\section{METODOLOGI PENELITIAN}

Lokasi penelitian adalah di SD Negeri Tumbang Kalemei yang beralamat di Jln Desa Tumbang Kalemei, Tumbang Kalemei, Kec. Katingan Tengah, Kab. Katingan, Prop. Kalimantan Tengah Waktu pelaksanaan direncanakan selama tiga bulan mulai tanggal 03 Februari s/d 03 April 2019.

Penelitian ini dilakukan dengan metode penelitian tindakan kelas yang berlangsung selama 2 siklus. Masing-masing siklus terdiri dari tahapan perencanaan, pelaksanaan, observasi dan refleksi. Metode penelitian yang dilakukan peneliti diuraikan sebagai berikut:

\section{Perencanaan Awal}

Langkah awal yang direncanakan pada penilitian tindakan sekolah ini terdiri dari beberapa kegiatan, yakni mengidentifikasi masalah, mengajukan proposal dan mempersiapkan instrument.

\section{Siklus pertama.}

a. Perencanaan 
Pada tahap ini, peneliti merencanakan langkah-langkah sebagi berikut:

1) Mengidentifikasi jumlah guru yang sudah melakasankan inovasi pembelajaran.

2) Meminta guru untuk melakukan inovasi pembelajaran

3) Peneliti memeriksa administrasi guru dan pola mengajar secara kuantitas dan kulitatif.

4) Peneliti mengidentifikasi permasalahan yang ditemukan.

5) Menyusun rencana tindakan (berupa penjadwalan supervise individual atau kelompok disesuaikan dengan temuan pada identifikasi masalah)

b. Pelaksanaan

Pada tahap ini peneliti
melaksanakan rencana tindakan supervise individual/kelompok untuk menilai administrasi guru yang sudah dikumpulkan sebelumnya. Pelaksanaan supervise dilakukan dengan pertemuan individual office-conference. Hal ini dilakukan terutama kepada guru yang tidak mengumpulkan perangkat pembelajaran, untuk mengetahui penyebab/masalahnya. Tahap ini peneliti rencanakan berlangsung selama 2 minggu dan dilaksanakan bersama-sama dengan kolaborator.

c. Observasi

Pada tahap ini peneliti melakukan kegiatan observasi terhadap seluruh kejadian yang terjadi selama tahap pelaksanaan dan mengobservasi hasil awal yang dicapai pada pelaksanaan tindakan siklus 1 . Selain itu peneliti juga mengidentifikasi masalah-masalah lanjutan yang timbul dari pelaksanaan tindakan di siklus 1 .

d. Refleksi

Pada tahap refleksi, peneliti melakukan evaluasi terhadap tindakan dan data-data yang diperoleh. Kemudian dilanjutkan dengan pertemuan bersama kolaborator untuk membahas hasil evaluasi dan penyusunan langkah-langkah untuk siklus kedua.

\section{Siklus kedua}

a. Perencanaan

Tahap perencanaan pada siklus kedua ini, peneliti melakukan pertemuan dengan kolaborator untuk menyusun penjadwalan supervise kelas dan menyiapkan instrument supervise untuk siklus kedua.

b. Pelaksanaan

Pada tahap ini, guru-guru yang sudah siap perangkat perencanaan pembelajarannya disupervisi kelas oleh peneliti. Hal ini untuk melihat kesesuaian perencanaan pembelajaran dengan pelaksanaan pemelajaran.

c. Observasi

Di tahap observasi siklus kedua, peneliti mengobservasi kesesuaian perencanaan pembelajaran dengan pelaksanaan pembelajaran serta melihat keberterimaan siswa dalam proses belajar mengajar. Pada tahap ini pula, peneliti mengumpulkan data-data yang terjadi selama tahap pelaksanaan.

d. Refleksi

Pada tahap refleksi siklus kedua, peneliti melakukan evaluasi bersama guru yang disupervisi terhadap hasil observasi di siklus kedua. 
Untuk melihat kesesuaian perencanaan tindakan tersebut, maka berikut ini peneliti melaporkan pelaksanaan tindakan sebagai berikut:

\section{Tahap perencanaan Awal}

Langkah awal yang direncanakan pada penilitian tindakan sekolah ini terdiri dari beberapa kegiatan, yakni:

a. Identifikasi masalah

Pengidentifikasian masalah dilakukan oleh peneliti dengan menggunakan data penyerahan perangkat pembelajaran tahun pelajaran 2018/2019 ini dilakukan pada bulan Maret 2019.

b. Penyusunan PTS

Penyusunan PTS dilaksanakan oleh peneliti pada tanggal 05 Maret 2019

c. Mempersiapkan instrument

Pada tahap ini, peneliti menyiapkan seluruh instrument penelitian berupa lembar pengamatan supervise yang terdiri dari data jumlah guru yang membuat administrasi dan pola mengjar dari supervisi yang telah ada.

\section{Siklus pertama.}

a. Perencanaan

Tahap perencanaan pelaksanaan siklus 1 dilaksanakan peneliti pada minggu pertama Maret 2019. Kegiatan yang dilakukan pada tahap ini dapat dilihat pada table pelaksanaan kegiatan dibawah ini.

b. Pelaksanaan

Pelaksanaan tindakan pada siklus pertama dilaksanakan pada minggu ke1 Maret 2019. Secara lebih rinci dapat dilihat pada table berikut.

c. Observasi
Pada tahap ini peneliti melakukan kegiatan observasi terhadap seluruh kejadian yang terjadi selama tahap pelaksanaan tindakan siklus 1. Selain itu peneliti juga mengidentifikasi masalah-masalah lanjutan yang timbul dari pelaksanaan tindakan di siklus 1 .

d. Refleksi

Pada tahap refleksi, peneliti melakukan evaluasi terhadap tindakan dan datadata yang diperoleh. Kemudian dilanjutkan dengan pertemuan bersama kolaborator untuk membahas hasil evaluasi dan penyusunan langkahlangkah untuk siklus kedua.

\section{Siklus kedua}

a. Perencanaan

Tahap perencanaan pada siklus kedua ini, peneliti melakukan pertemuan dengan kolaborator untuk menyusun penjadwalan supervise kelas dan menyiapkan instrument supervise untuk siklus kedua.

b. Observasi

Di tahap observasi siklus kedua, peneliti mengobservasi kesesuaian perencanaan pembelajaran dengan pelaksanaan pembelajaran serta melihat keberterimaan siswa dalam proses belajar mengajar. Pada tahap ini pula, peneliti mengumpulkan data-data yang terjadi selama tahap pelaksanaan.

c. Refleksi

Pada tahap refleksi siklus kedua, peneliti melakukan evaluasi bersama guru yang disupervisi terhadap hasil observasi di siklus kedua 


\section{HASIL DAN PEMBAHASAN}

1. Hasil Siklus I

a. Tahap perencanaan

Pada tahap ini peneliti mempersiapkan perangkat penelitian. Selain itu juga dipersiapkan lembar observasi.

b. Tahap kegiatan dan pelaksanaan

Pelaksanaan kegiatan belajar mengajar untuk siklus I dilaksanakan pada tanggal 08 Maret 2019 di SD Negeri Tumbang Kalemei dengan jumlah guru sebanyak 8 orang. Pengamatan (observasi) dilaksanakan bersamaan dengan pelaksanaan belajar mengajar. Sebagai pengamat adalah peneliti dibantu oleh seorang guru. Terlihat bahwa data guru yang nilai skor diatas minimat 75 adalah sebesar $62,50 \%$.

2. Siklus II

a. Tahap perencanaan

Pada tahap ini peneliti mempersiapkan perangkat penelitian. Selain itu juga dipersiapkan lembar observasi.

b. Tahap kegiatan dan pelaksanaan

Pelaksanaan kegiatan belajar mengajar untuk siklus II dilaksanakan pada tanggal 15 Maret 2019 di SD Negeri Tumbang Kalemei dengan jumlah guru sebanyak 8 orang. Pengamatan (observasi) dilaksanakan bersamaan dan pelaksanaan belajar mengajar. Sebagai pengamat adalah peneliti dibantu oleh seorang guru. Terlihat bahwa data guru yang nilai skor diatas minimat 75 adalah sebesar $87,50 \%$.
Dalam pelaksankan inovasi pembelajaran guru sudah melakukan inovasi sesuai apa yang telah di arahkan oleh kepala sekolah dan imotivasi. Hal ini ditunjukkan dengna bukti ilmiah adanya peningkatan dari siklus I sebesar $62,50 \%$ menjadi siklus II sebesar $87,50 \%$. Berdasarkan analisis data yang diperoleh dari presensi kehadiran guru dan keaktifan dalam membuat administrasi guru serta dalam mengajar, diperloeh data bahwa guru mulai menerapkan inovasi dalam pembelajaran di kelas.

\section{KESIMPULAN}

Berdasarkan hasil penelitian yang terurai, kami dapat menyimpulkan bahwa: pemberdayaan guru oleh kepala sekolah dapat meningkatkan optimalisasi prestasi kerja guru, hal tersebut dapat dilihat dengan kenaikan siklus I sebesar 62,50\% meningkat menjadi $87,50 \%$ pada siklus II.

Harapannya kawan-kawan kepala sekolah, terus mmberi arahan dan kepemimpinan yang baik dalam lembaga pendidikan agar didapat SDM guru yang andal dan mau berinovasi dalam pembelajaran. Kemudian kepada pengawas diharapkan dapat memberikan masukan yang lebih jelas dan terarah dalam pembinaan terhadap guru.

\section{DAFTAR PUSTAKA}

Adimiharja, K.(2002). Metode Penelitian Sosial. Bandung:PT. Remaja Rosdakarya

Ali, M. (1987). Guru Dalam Proses Belajar Mengajar. Bandung : Sinar Baru Algesindo

Anwar, Idochi. (1984). Evaluasi dan Pengukuran Pendidikan. Jakarta : Depdikbud 
Aqib, Zainal.(2002). Profesionalisme Guru

Dalam Pembelajaran. Surabaya: Insan Cendikia

Arikunto, Suharsimi. (1998). Prosedur Penelitian (Suatu Pendekatan Praktek). Jakarta : Rineka Cipta.

BAKN.(1980). Daftar Penilaian Pelaksanaan Pekerjaan Dan Daftar Urut Kepangkatan Pegawai Negeri Sipil. Jakarta: PT. Analtu.

DEPDIKBUD.(1989). Kamus Besar Bahasa Indonesia. Jakarta : Balai Pustaka

Dharma, Agus.(1999). Manajemen Prestasi Kerja. Jakarta : CV Rajawali

Engkoswara. (1999). Dasar-dasar Administrasi Pendidikan. Jakarta : CV Rajawali

Fauzan, Mohamad. (2004). Kontribusi Efektivitas Manajemen Terhadap Kinerja Guru. Tesis Administrasi Pendidikan : Tidak Diterbitkan.

Flippo, E.B. (1995). Manajemen Personalia Edisi 6, Alih Bahasa Moh Mas'ud. Jakarta : Erlangga.

Mundu Kabupaten Cirebon). Tesis Program Pasca Sarjana Upi.

Hadari, Nawawi. (1998). Administrasi Penmdidikan. Jakarta : CV Haji Masagung

Hariyanto, Anita B. (2001). Keterampilan Kepemimpinan. Jakarta : Mitra Media. Hasibuan, Malayu SP. (2001). Manajemen Sumber Daya Manusia. Jakarta : Bumi Aksara

Mangkunegara, Anwar Prabu. (2001). Manajemen Sumber Daya Manusia Perusahaan. Bandung: PT Remaja Rosdakarya.

Moekijat. (1989). Manajemen Tenaga Kerja dan Hubungan Kerja. Bandung : Pionir Jaya
Mulyasa, E. (2006). Menjadi Kepala Sekolah Yang Profesional dalam Konteks Menyukseskan MBS dan KBK. Bandung : PT Remaja Rosdakarya.

Nazir, M. (1999). Metode Research (Penelitian Ilmiah). Jakarta : Ghalia Indonesia.

Nasution, S. (1987). Penelitian Pendidikan, Prosedur dan Strategi. Bandung : Bumi Aksar.

Permadi, Ade Salahudin \& Muchlis Saini. 2017. Upaya Meningkatkan Hasil Belajar IPA melalui Penerapan Media Pembelajaran Berbasis Multimedia Peserta Didik. Bitnet: Jurnal Pendidikan Teknologi Informasi, 2(2):20-26.

Putra, Chandra Anugrah. 2017. Pemanfaatan Teknologi Gadget Sebagai Media Pembelajaran. Bitnet : Jurnal Pendidikan Teknologi Informasi, 2(2):1-10.

Riadin, Agung. 2016. Upaya Meningkatkan Hasil Belajar Ipa Dengan Menggunakan Pendekatan Saintifik Pada Peserta Didik Kelas V SDS Muhammadiyah Plus Kabupaten Kapuas Tahun Pelajaran 2014/2015.

Sahlan Hadi, Akdon. (2005). Aplikasi Statistika dan Metode Penelitian untuk Administrasi dan Manajemen. Bandung : Dewa Ruchi.

Samsudin, Sadili. (2005). Manajemen Sumber Daya Manusia. Bandung : CV Pustaka Setia

Sedarmayanti. (2001). Sumber Daya Manusia dan Produktivitas Kerja. Bandung : CV Mandar Maju.

Siagian, S.P. (1992). Organisasi, Kepemimpinan dan Perilaku 
Organisasi. Jakarta : PT Toko Gunung Agung.

Siagian, S.P. (2002). Kiat Meningkatkan Produktivitas Kerja. Jakarta : PT Rineka Cipta.

Stewart Aileen Mitchell. (2002). Empowering People. Yogyakarta : Konisius.

Strauss \& Stayles. (1981). Manajemen Personalia : Segi Manusia Dalam Organisasi. Penerjemah NY L Mulyana. Jakarta : Percetakan Sapodadi.

Subino. (1982). Bimbingan Skripsi : Rancangan, Pelaksanaan, Analisis dan Penelitian. Bandung: ABA Yapari.

Sudjana. (1996). Metode Statistika. Bandung : Transito

Sutisna, Oteng. (1983). Administrasi Pendidikan (Dasar dan Teoritis untuk Praktek Profesional). Bandung : Angkasa.

Sufaryarma. (2003). Manajemen Pendidikan. Bandung : Alfabeta

Sugiyono. (2000). Metode Penelitian Administrasi. Bandung : Alfabeta

Surakhmad, Winarno. (1998). Pengantar Penelitian Ilmiah. Bandung : Transito Syadam, Ghauzali. (1996). Manajemen Sumber Daya Manusia. Jakarta : Gunung Agung.

Syafarudin. (2002). Manajemen Mutu Terpadu dalam Pendidikan. Jakarta : Grasindo
Tim Dosen Adpend UPI. (2008). Manajemen Pendidikan. Bandung : Alfabeta

Tim Dosen MKDK. (2002). Pengelolaan Pendidikan. Bandung : Universitas Pendidikan Indonesia. . (2009). Undang-undang Guru dan Dosen. Bandung : Fokus Media Universitas Pendidikan Indonesia (UPI). (2008). Pedoman Penulisan Karya Ilmiah

(Laporan Buku, Makalah, Skripsi, Tesis dan Disertasi). Bandung : Depdiknas UPI.

Usman Uzer. (1995). Menjadi Guru Profesional. Bandung : PT Remaja Rosdakarya

Wahjusumidjo. (2002). Kepemimpinan Kepala Sekolah (Tinjauan Teori dan Permasalahannya). Jakarta : Raja Grafindo Persada.

Wasito, Hermawan. (1995). Pengantar Metodelogi Penelitian. Jakarta : Pustaka Utama Gramedia.

Winardi. (1971). Organisasi Perkantoran dan Motivasi. Bandung : Alumni Yanwar Yosef. (2005). Pengaruh Peran Kepala Sekolah Sebagai Leader Terhadap Prestasi Kerja Guru Sekolah Dasar Negeri Se-Kecamatan Cidadap Kota Bandung. Bandung : Skripsi Jurusan Administrasi Pendidikan UPI. 